\title{
Is Age an Independent Risk Factor for Histopathology of Colorectal Polyps? A Retrospective Analysis
}

\section{Yaş Kolonik Polip Histopatolojisi için Bağımsız Bir Risk Faktörü Müdür? Retrospektif Analiz}

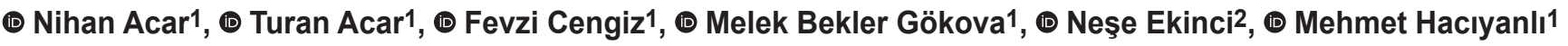 \\ ${ }^{1}$ İzmir Katip Çelebi University, Atatürk Training and Research Hospital, Clinic of General Surgery, İzmir, Turkey \\ 2İzmir Katip Çelebi University, Atatürk Training and Research Hospital, Clinic of Pathalogy, İzmir, Turkey
}

\section{HIIIIIII ABSTRACT}

Aim: Colorectal cancer and its precursor lesions are quite common in developed countries. Data on the prevalence of lesions located in the right colon have been reported to range from 20.5 to $48.1 \%$ depending on the gender and advanced age. Today, many countries are conducting studies for disseminating the screening programmes in order to detect and treat polyps at an early stage. In this paper, we aimed to evaluate the relationship that exists between the patient's age and the polyp localisation with histopathology of colorectal polyp.

Method: In our endoscopy unit, 789 patients underwent colonoscopy in the last two years. Among these, a total of 724 patients who met the criteria were included in the study group. The demography of the patients and histopathological data of the polyps were evaluated.

Results: Of the 724 patients included in the study, 317 had at least one pathology detected by colonoscopy. Of these, $57.4 \%$ had polyp, $13.6 \%$ had malignancy, $8.2 \%$ had diverticula, $6.9 \%$ had both diverticula and polyp, 5.4\% had ulcerative colitis, 3.8\% had Crohn's colitis, $4.1 \%$ had anastomotic stricture, and $0.6 \%$ had lipoma. The prevalence of precancerous and cancerous polyps was observed to be significantly higher in the left colon localisation and among cases aged 50 and over. No significant difference was noticed between polyp type and polyp localisation.

Conclusion: Age is an independent risk factor for histopathology of colorectal polyps. Therefore, we believe that screening programmes should be disseminated.

Keywords: Colonoscopy, colorectal polyps, risk factor

\section{HIIIIII| ÖZ}

Amaç: Kolorektal kanser ve öncüleri gelişmiş ülkelerde oldukça yaygındır. Sadece sağ taraftaki lezyonların prevalansı için mevcut literatürdeki tahminler, cinsiyet ve ilerleyen yaşla ilişkili olarak \%20,5 ile 48,1 arasında değişmektedir. Günümüzde birçok ülkede, poliplerin erken evrede tespit ve tedavi edilebilmesi amacıyla, tarama programlarının yaygınlığını artırıcı çalışmalar yapılmaktadır. Bizde bu yazımızda, hasta yaş ve polip lokalizasyonunun, kolorektal polip histopatolojisi ile ilişkisini değerlendirmeyi amaçladık.

Yöntem: Kliniğimizde son 24 ayda 789 hastaya kolonoskopi yapıldı. Bu hastalardan kriterlere uyan 724'ü çalışma grubuna dahil edildi. Hastaların klinik ve poliplerin histopatolojik verileri değerlendirildi.

Bulgular: Çalışmaya dahil edilen 724 hastanın 317'sinin kolonoskopisin de patoloji mevcut idi. Bunlardan \%57,4'ünde polip, \%13,6'sında malignite, \%8,2'sinde divertikül, \%6,9'unda divertikül ve polip, \%5,4'ünde ülseratif kolit, \%3,8'inde crohn koliti, \%4,1'inde anastomoz darlığl ve \%0,6'sında lipom tespit edildi. Sol kolon lokalizasyonunda ve 50 yaş ve üstü olgularda prekanseröz ve kanserli polip prevalansının anlamlı derecede yüksek olduğu gözlendi. Polip tipi ile polip lokalizasyonu arasında anlamlı fark yoktu.

Sonuç: Yaş, kolorektal poliplerin histopatolojisi için bağımsız bir risk faktörüdür. Bu nedenle, tarama programlarının yaygınlaştırılması gerektiğine inaniyoruz.

Anahtar Kelimeler: Kolonoskopi, kolorektal polip, risk faktörü

Address for Correspondence/Yazışma Adresi: Nihan Acar, MD,

İzmir Katip Çelebi University, Atatürk Training and Research Hospital, Clinic of General Surgery, İzmir, Turkey

E-mail: cosgunnihan@hotmail.com ORCID ID: orcid.org/0000-0003-0720-3794

Received/Geliş Tarihi: 13.04.2020 Accepted/Kabul Tarihi: 10.05.2020

${ }^{\circ}$ Copyright 2020 by Turkish Society of Colon and Rectal Surgery

Turkish Journal of Colorectal Disease published by Galenos Publishing House. 


\section{Introduction}

Colorectal cancer (CRC) has the second highest incidence of digestive system cancers according to the American Cancer Society (ACS). ${ }^{1}$ In Turkey, it is the third most common cancer among men and women. ${ }^{2}$ CRC and its precursor lesions are quite common in developed countries. Adenoma-carcinoma sequence, which aims to schematise the process of CRC development, is widely accepted. ${ }^{3}$ Data on the prevalence of precursor lesions have been reported to range from 20.5 to $48.1 \%$ depending on the gender and advanced age. ${ }^{4}$

Studies have shown that age is one of the most important risk factors for developing colorectal adenoma, especially age of $\geq 65$ years is reported to be related with higher prevalence rates for advanced adenomas and CRC. ${ }^{5}$ Also, report has it that the left colon polyps and carcinomas detected in colonoscopy have a higher incidence than the right-sided colon. ${ }^{4,6}$ Therefore, many countries today have been conducting studies for disseminating the screening programmes in order to detect and treat polyps at an early stage. $^{7}$

Regular screening is therefore recommended for CRC in adults 45 years of age and older with an average-risk by the ACS Guideline (2018). ${ }^{8}$ On the other hand, the American Society for Gastrointestinal Endoscopy emphasises that 50 years is the age to begin CRC screening for Caucasians with an average-risk, since the rate of adenoma detection at this age reaches $25 \%$ and $15 \%$ in men and women, respectively. ${ }^{9}$ In this study, our aim is to evaluate the relationship between the patient's age and the polyp localisation with histopathology of colorectal polyp.

\section{Materials and Methods}

The study protocol was approved by the institutional Ethics Committee. A written, informed consent was obtained from each patient. The study was conducted in accordance with the principles of the Declaration of Helsinki.

The medical records of patients, who underwent colonoscopy in the last two years in the surgical endoscopy unit of our department were evaluated retrospectively. Within this period; a total of 789 colonoscopy procedures had been performed (with the indications of positive faecal occult blood testing, rectal bleeding or hematochezia, regular health examination and constipation), and among them, 724 patients' medical records were evaluated. Of these 724 patients, 317 in whom a colonic pathology was detected were included in the study group.

The following inclusion criteria were used for patient selection: (1) the patients who underwent complete colonoscopy (caecal intubation), and (2) the patients who underwent a polypectomy and/or biopsy. The 65 patients who had (1) incomplete colonoscopy, (2) underwent an endoscopic mucosal resection or endoscopic submucosal resection (not decided and performed in screening, their prior biopsy results were known and colonoscopy was performed in them with a therapeutic purpose), and/or (3) in which polypectomy could not be performed (due to taking anticoagulant drugs, multiple comorbid conditions, etc.) (Since we did not perform polypectomy in the same session due to the risk factors, we did not know the histopathology of those polyps.) were excluded.

The following parameters were analysed for all patients: age, sex, presenting complaint, polyp location, and histological subtype of polyp. Precise characteristics of the colorectal polyps (that is, number, size, form and location) were documented in the colonoscopy reports by endoscopists.

Initially, the patients were classified into three groups according to their age ( $<40$ years old, $40-49$ years old, and $\geq 50$ years). After that, colorectal polyps were divided into four groups: The right-sided, left-sided, rectum and multiple lesions. The polyps located proximal to the splenic flexure were considered right-sided (including the caecum, ascending colon and transverse colon), whereas those that were distal to the splenic flexure were considered left-sided (including the descending colon, sigmoid colon and rectum). Histopathological findings and degree of dysplasia (low and high) were also analysed.

\section{Colonoscopy Procedure}

Four trained endoscopists carried out the procedures. An Olympus Evis Exera III (CF-H260/CF-Q260) (Olympus, Tokyo, Japan) was used to conduct all investigations.

Sodium Dihydrogen Phosphate (B.T. Enema $210 \mathrm{ml}$ ) and Sennozid A+B Ca (X-M diet $150 \mathrm{ml}$ ) as a purgative was used for all patients for bowel preparation. Sedoanalgesia was performed by the anaesthesiologist. Polypectomies were performed using standard biopsy forceps (for polyps $<5 \mathrm{~mm}$ ) or polypectomy snares for larger polyps (>5 mm).

\section{Statistical Analysis}

The data was analysed using the SPSS statistical software, version 17. Common statistics were applied in order to estimate the significance of the results. Chi-square test, Mann-Whitney nonparametric test and Fischer's exact test were used were necessary. Differences were considered to be significant if $\mathrm{p}<0.05$.

\section{Results}

At least one pathology was detected by colonoscopy in 317 (43.8\%). Of these $317,57.4 \%(n=182)$ had polyp, $13.6 \%$ $(\mathrm{n}=43)$ had malignancy, $8.2 \%(\mathrm{n}=26)$ had diverticula, $6.9 \%$ 
$(n=22)$ had both diverticula and polyp, 5.4\% $(n=17)$ had ulcerative colitis, 3.8\% $(n=12)$ had Crohn's colitis, 4.1\% $(n=13)$ had anastomotic stricture, and $0.6 \% \quad(n=2)$ had lipoma.

The characteristics of patients who had polyp are shown in Table 1. Among 182 patients with polyps, 57.7\% were male. The mean age of these patients was $60.3 \pm 6,26$ (3786 ) and $85.8 \%$ of the patients were $\geq 50$ years of age. The presenting complaints/symptoms were positive faecal occult blood $(30.8 \%)$, rectal bleeding or hematochezia (14.3\%), constipation (8.8\%) and regular health examination (46.1\%). A maximum of two polys was found in $72 \%$ of the patients. Of all polyps, 142 (78.1\%) were adenomatous polyps (APs), 31 (17\%) were hyperplastic or non-adenomatous polyps

Table 1. The general characteristics of patients with polyp

\begin{tabular}{|c|c|}
\hline Features & n (182) \\
\hline \multicolumn{2}{|l|}{ Gender (n, \%) } \\
\hline Male & $111(57.7)$ \\
\hline Female & $71(42.3)$ \\
\hline Mean age (year) (range) & $\begin{array}{l}60.3 \pm 6,26 \\
(37-86)\end{array}$ \\
\hline \multicolumn{2}{|l|}{ Age $(n, \%)$} \\
\hline$<40$ & $1(0.5)$ \\
\hline 40- 49 & $25(13.7)$ \\
\hline$\geq 50$ & $156(85.8)$ \\
\hline \multicolumn{2}{|l|}{ Presenting complaint (n, \%) } \\
\hline Positive faecal occult blood testing & $56(30.8)$ \\
\hline Rectal bleeding or hematochezia & $26(14.3)$ \\
\hline Regular health examination & $84(46.1)$ \\
\hline Constipation & $16(8.8)$ \\
\hline \multicolumn{2}{|l|}{ Number of polyp (n, \%) } \\
\hline $1-2$ & $131(72)$ \\
\hline$>2$ & $51(28)$ \\
\hline \multicolumn{2}{|l|}{ Histopathology of colorectal polyp } \\
\hline Adenomatous polyps & $142(78.1)$ \\
\hline Tubular adenomas (Low dysplasia) & $75(41.4)$ \\
\hline Tubular adenomas (High dysplasia) & $28(15.4)$ \\
\hline Tubulovillous adenomas (Low dysplasia) & $11(6)$ \\
\hline Tubulovillous adenomas (High dysplasia) & $15(8.2)$ \\
\hline Villous adenomas (Low dysplasia) & $7(3.8)$ \\
\hline Villous adenomas (High dysplasia) & $6(3.3)$ \\
\hline Hyperplastic or non-adenomatous polyps & $31(17)$ \\
\hline Intra-mucosal carcinoma & $9(4.9)$ \\
\hline \multicolumn{2}{|l|}{ Polyp localisation } \\
\hline Right colon & $40(22)$ \\
\hline Left colon & $70(38.4)$ \\
\hline Rectum & $40(22)$ \\
\hline Multiple & $32(17.6)$ \\
\hline
\end{tabular}

and 9 (4.9\%) were intra-mucosal carcinoma. The 142 APs comprised 103 (56.8\%) tubular adenomas, 26 (14.2\%) tubulovillous adenomas and 13 (7.1\%) villous adenomas. Among the APs, 49 (26.9\%) were noted to have high grade dysplasia (HGD). Of the 182 patients with polyp; 41 (22.5\%), 69 (38\%), 41 (22.5\%) and 31 (17\%) polyps were detected in the right colon, the left colon, the rectum and multiple locations, respectively.

$85.8 \%$ of all the polyps and $79.1 \%$ of all the malignancies were detected in cases $\geq 50$ years of age (Table 2 ). There were significant statistical differences between groups when polyps and malignancy were compared according to age.

When the localisation of polyps by age was evaluated, the polyps in patients under the age of 50 were observed most commonly in the rectum, while those in patients 50 years of age and above were in the left colon (Table 3 ). Hyperplastic or non-APs were most commonly observed in $<50$ years of age, while intra-mucosal carcinoma was observed in $\geq 50$ years of age (Table 4). Additionally, polyp type analysis by localisation, hyperplastic or non-adenomatous polyp (s), adenomatous polyp (s) and intra-mucosal carcinoma were most commonly detected in the left colon (Table 5). According to these results, there was a significant difference between the patient's age and polyp (s) localisation and type $(\mathrm{p}<0.05)$, but there was no difference between polyp type and localisation. Also, proximal rectum was the most common localisation for the rectal polyps.

\section{Discussion}

The present study retrospectively analysed the clinical and pathological characteristics of colorectal polyps and the relation between colorectal polyp localisation,

Table 2. Polyp and cancer detection analysis by age

\begin{tabular}{lcll|} 
Features & $\begin{array}{c}\text { Age }<50 \\
\mathbf{n}(\%)\end{array}$ & $\begin{array}{l}\text { Age } \geq 50 \\
\mathbf{n}(\%)\end{array}$ & p value \\
\hline Polyp (s) $(\mathrm{n}=182)$ & $26(14.2)$ & $156(85.8)$ & $<0.01^{*}$ \\
Malignancy (n=43) & $9(20.9)$ & $34(79.1)$ & $<0.01^{*}$
\end{tabular}

Table 3. Polyp (s) localisation analysis by age

\begin{tabular}{llll}
$\begin{array}{l}\text { Polyp (s) } \\
\text { localisation }\end{array}$ & Age $<50 \mathrm{n}(\%)$ & Age $\geq 50 \mathrm{n}(\%)$ & p value \\
\hline Right colon & $4(17.6)$ & $36(23)$ & \\
Left colon & $7(26.5)$ & $63(42.2)$ & $<0.01^{*}$ \\
Rectum & $12(41.2)$ & $28(17.6)$ & \\
Multiple & $3(14.7)$ & $29(18.2)$ & \\
Total (n) & 26 & 156
\end{tabular}


Table 4. Histopathology of colorectal polyp analysis by age

\begin{tabular}{llll} 
Age,$(\mathrm{n})$ & $\begin{array}{l}\text { Polyp type, } \mathrm{n}(\%) \\
\text { Hyperplastic or non-adenomatous, } \\
31(17)\end{array}$ & $\begin{array}{l}\text { Adenomatous, } \\
142(78.1)\end{array}$ & $\begin{array}{c}\text { Intra-mucosal carcinoma, } \\
9(4.9)\end{array}$ \\
\hline $50(26)$ & $20(64.5)$ & $84(59.2)$ & $2(33.3)$ \\
$\geq 50(156)$ & $11(35.5)$ & $58(40.8)$ & $6(66.7)$
\end{tabular}

Table 5. Histopathology of colorectal polyp analysis by localisation

\begin{tabular}{|c|c|c|c|c|}
\hline & Polyp type, n (\%) & & & \\
\hline $\begin{array}{l}\text { Polyp localisation, } \\
\text { n (\%) }\end{array}$ & $\begin{array}{l}\text { Hyperplastic or non-adenomatous, } \\
31 \text { (17) }\end{array}$ & $\begin{array}{l}\text { Adenomatous, } \\
142(78.1)\end{array}$ & $\begin{array}{l}\text { Intra-mucosal carcinoma, } \\
9(4.9)\end{array}$ & $\mathrm{p}$ value \\
\hline Right colon & $6(19.4)$ & $33(23.2)$ & $1(11.1)$ & \\
\hline Left colon & $10(32.3)$ & $54(38.1)$ & $6(66.7)$ & \\
\hline Rectum & $7(22.6)$ & $31(21.8)$ & & \\
\hline Upper & $3(42.9)$ & $16(51.6)$ & $2(22.2)$ & 0.256 \\
\hline Middle & $3(42.9)$ & $9(29)$ & $2(100)$ & \\
\hline Lower & $1(14.2)$ & $6(19.4)$ & & \\
\hline Multiple & $8(25.7)$ & $24(16.9)$ & - & \\
\hline
\end{tabular}

histopathology and patient's age in our patient group.

Advancing age has been reported to be an independent risk factor for the development of colorectal polyps and carcinoma..$^{5,10}$ However, publications evaluating the relationship between patient's age, polyp localisation and polyp histopathology are limited. In the present study, it was observed that age of patient with polyp was an independent risk factor for polyp histopathology, but polyp localisation did not have any effect on histopathology.

Current reports have identified that old age, obesity, smoking, alcohol, BMI, diet, physical activity, medication, and/or hormone replacement therapy are independent risk factors with colorectal polyps. ${ }^{11,12,13}$ Age is equally an important factor in both men and women. More than 50\% of CRC cases are diagnosed after the age of 70 years and only $10 \%$ of the cases are detected before the age of $55 .{ }^{14}$ Another study with the participants between the age of 20 and 79 showed that the prevalence of colorectal adenoma increased significantly with age. ${ }^{15}$ The effect of patient sex on polyp incidence is still controversial, whereas men have a higher risk of developing APs compared to women. ${ }^{16,17}$ However, Kaminski et al. ${ }^{18}$ reported that almost similar as CRC family history, there is an increased risk in male sex.

In our study, 23\% of the patients who underwent colonoscopy were found to have polyp and the risk of polyp increased significantly with age. Median age of the patients with polyps was similar to other studies, in which the mean was 60.3 years. ${ }^{19}$ In addition, the majority of the patients with polyps were male.

Determining the histopathological features of the polyps with colonoscopy precisely is quite challenging. This can only be achieved with the removal of the polyp followed by the histopathological examination. APs which includes dysplasia is the most common type detected with colonoscopy. While these polyps can be found in 5-10\% of the general population, this rate increases up to $60 \%$ in the ninth decade..$^{20}$ APs constituted $78.1 \%$ of our cases and among them tubular polyps were the most common type (56.8\%), compared to other studies. ${ }^{21}$

Risk for developing CRC is associated with histological type and localisation of the polyp. The present study has shown that polyps were more frequently located in the left colon and the rectum (60.5\%), a finding that is in agreement with previous studies ${ }^{22,23}$ and left sided polyp had more tendency to show HGD and intra-mucosal carcinoma. In a study by Patel et al, it was demonstrated that the prevalence of rightsided lesions increased with advanced aged. ${ }^{24}$ Therefore, that study indicates the importance of evaluating the entire colon segments in elderly population. However, complete colonoscopy may not always be achieved in this patient group due to increased risk of complications, poorer bowel preparation and higher incidence of comorbidities. 


\section{Study Limitations}

This study had several limitations: 1) Study was performed in a single academic centre with limited numbers of sample and 2) It was a retrospective study where the sizes of all adenomas were not found.

\section{Conclusion}

Age is an independent risk factor for histopathology of colorectal polyps. We therefore believe that screening programs should be disseminated, the quality of endoscopic interventions should be inspected and improved.

\section{Ethics}

Ethics Committee Approval: The study protocol was approved by the institutional Ethics Committee (date: 12.08.2019; number: 618).

Informed Consent: Written informed consent was obtained from the patient for the publication of this report and any accompanying images.

Peer-review: Internally peer reviewed.

\section{Authorship Contributions}

Concept: T.A., N.A., Design: T.A., N.A., F.C., Supervision: N.E., M.B.G., M.H., Materials: T.A., N.A., Data Collection and/or Processing: T.A., N.A., Analysis and/or Interpretation: F.C., N.E., M.B.G., M.H., Literature Search: T.A., N.A., Writing: T.A., N.A.

Conflict of Interest: No conflict of interest was declared by the authors.

Financial Disclosure: The authors declared that this study received no financial support.

\section{References}

1. American Cancer Society. Cancer facts and figures 2016. Atlanta: American Cancer Society, 2016.

2. 2014 Yllı Türkiye Kanser İstatistikleri. Türkiye istatistik kurumu. Available from: https://hsgm.saglik.gov.tr/tr/kanser-istatistikleri/yillar/2014-yiliturkiye-kanser-istatistikleri.html

3. Nouraie M, Hosseinkhah F, Brim H, Zamanifekri B, Smoot DT, Ashktorab H. Clinicopathological features of colon polyps from African-Americans. Dig Dis Sci 2010;55:1442-1449.

4. McCashland TM, Brand R, Lyden E, de Garmo P; CORI Research Project. Gender differences in colorectal polyps and tumors. Am J Gastroenterol. 2001;96:882-886

5. Heitman SJ, Ronksley PE, Hilsden RJ, Manns BJ, Rostom A, Hemmelgarn BR. Prevalence of adenomas and colorectal cancer in average risk individuals: A systematic review and meta-analysis. Clin Gastroenterol Hepatol 2009; 7:1272-1278.

6. Almadi MA, Alharbi O, Azzam N, Wadera J, Sadaf N, Aljebreen AM Prevalence and characteristics of colonic polyps and adenomas in 2654 colonoscopies in Saudi Arabia. Saudi J Gastroenterol 2014;20:154-161.

7. Navarro M, Nicolas A, Ferrandez A, Lanas A. Colorectal cancer population screening programs worldwide in 2016: An update. World J Gastroenterol 2017;23:3632-3642
8. Wolf AMD, Fontham ETH, Church TR, Flowers CR, Guerra CE, LaMonte SJ, Etzioni R, McKenna MT, Oeffinger KC, Tina Shih YC, Walter LC, Andrews KS, Brawley OW, Brooks D, Fedewa SA, Manassaram-Baptiste D, Siegel RL, Wender RC, Smith RA. Colorectal cancer screening for averagerisk adults: 2018 guideline update from the American Cancer Society. CA Cancer J Clin 2018;68:250-281.

9. Williams JE, Holub JL, Faigel DO. Polypectomy rate is a valid quality measure for colonoscopy: results from a national endoscopy database. Gastrointest Endosc 2012;75:576-582.

10. Zhou L, Zhang H, Sun S, Huang M, Liu J, Xu D, Song M, Sun C, Li H, Zheng D, Fan Y, Liao Y, Wang P, Wu J. Clinical, endoscopic and pathological characteristics of colorectal polyps in elderly patients: Singlecenter experience. Mol Clin Oncol. 2017;7:81-87.

11. Bailie L, Loughrey MB, Coleman HG. Lifestyle risk factors for serrated colorectal polyps: a systematic review and meta-analysis. Gastroenterology 2017; 152:92-104

12. Chaput U, Alberto SF, Terris B, Beuvon F, Audureau E, Coriat R, Roche H, Gaudric M, Prat F, Chaussade S. Risk factors for advanced adenomas amongst small and diminutive colorectal polyps: a prospective monocenter study. Dig Liver Dis 2011:43:609-612.

13. Martínez ME, Sampliner R, Marshall JR, Bhattacharyya AK, Reid ME, Alberts DS. Adenoma characteristics as risk factors for recurrence of advanced adenomas. Gastroenterology 2001;120:1077-1083.

14. Center MM, Jemal A, Ward E. International trends in colorectal cancer incidence rates. Cancer Epidemiol Biomarkers Prev 2009;18:1688-1694.

15. Yang MH, Rampal S, Sung J, Choi YH, Son HJ, Lee JH, Kim YH, Chang DK, Rhee PL, Rhee JC, Guallar E, Cho J. The prevalence of colorectal adenomas in asymptomatic Korean men and women. Cancer Epidemiol Biomarkers Prev 2014;23:499-507.

16. de Oliveira AM, Anapaz V, Lourenço L, Graça Rodrigues C, Folgado Alberto S, Martins A, de Deus JR, Reis J. Is there a proximal shift in the distribution of colorectal adenomas? United European Gastroenterol J 2015;3:353-357.

17. Kolligs FT, Crispin A, Munte A, Wagner A, Mansmann U, Göke B. Risk of advanced colorectal neoplasia according to age and gender. PLoS One $2011 ; 6: 20076$

18. Kaminski MF, Wieszczy P, Rupinski M, Wojciechowska U, Didkowska J, Kraszewska E, Kobiela J, Franczyk R, Rupinska M, Kocot B, ChaberCiopinska A, Pachlewski J, Polkowski M, Regula J. Increased rate of adenoma detection associates with reduced risk of colorectal cancer and death. Gastroenterology 2017;153:98-105.

19. Parra-Blanco A, Gimeno-García AZ, Nicolás-Pérez D, Garcia C, Medina C, Díaz-Flores L, Grosso B, Jiménez A, Quintero E. Risk for high-grade dysplasia or invasive carcinoma in colorectal flat adenomas in a Spanish population. Gastroenterol Hepatol 2006;29:602-609.

20. Yano T, Yamamoto H, Sunada K, Miyata T, Iwamoto M, Hayashi Y, Arashiro M, Sugano K. Endoscopic classification of vascular lesions of the small intestine (with videos). Gastrointest Endosc 2008;67:169-172.

21. Spring KJ, Zhao ZZ, Karamatic R, Walsh MD, Whitehall VLJ, Pike T, Simms LA, Young J, James M, Montgomery GW, Appleyard M, Hewett D, Togashi K, Jass JR, Leggett BA. High prevalence of sessile serrated adenomas with BRAF mutations: a prospective study of patients undergoing colonoscopy. Gastroenterol 2006;131:1400-1407.

22. Hossne RS, Maranhão MF, Carvalho FA, Mendes FG. Estudo retrospectivo do resultado anatomopatológico de 100 polipectomias colonoscópicas realizadas na FMB-UNESP. Rev bras Coloproct 2007;27:251-255.

23. Zare-Mirzaie A, Abolhasani M and Aryamanesh A. Left sided colorectal adenomatous polyps have more risk for high grade dysplasia. Acta Med Iran 2013;51:172-177.

24. Patel $\mathrm{K}$ and Hoffman NE. The anatomical distribution of colorectal polyps at colonoscopy. J Clin Gastroenterol 2001;33:222-225. 